\title{
SUPPLEMENT
} Brian M. Gilfix MDCM, PhD, FRCPC,
DABCC, FACB

Financial Support:

Canadian Association of Medical Biochemists

\section{Report and abstracts of the Joint Annual Congress of the AMBQ- CAMB 2010}

Correspondence to:

Brian M. Gilfix

MUHC-Royal Victoria Hospital

687 Avenue des Pins O.

Montreal, Quebec H3A 1A1

E-mail: brian.gilfix@mcgill.ca 
The third joint congress of l'Association des Médicins Biochimistes du Québec (AMBQ) and the Canadian Association of Medical Biochemists (CAMB) was held this year from October 19 to 22 in Montreal. The setting was like last year the picturesque Hôtel Place d'Armes, which is situated in the historic Old Montreal district. There were over 60 attendees comprising both Specialists and Medical residents-in-training and representing the breadth of Canada from the Atlantic to the Pacific.

The scientific committee composed of Drs. Shaun Eintracht (SMBD-Jewish General Hospital (JGH)), Brian M. Gilfix (McGill University Health Centre (MUHC)), David Blank (MUHC), Elizabeth MacNamara (JGH), and Julie StCyr (St. Mary's Hospital (SMH)) arranged a series of informative and interesting scientific sessions.

Day 1 saw a training session for the medical residents conducted by Drs. David Keren (Wade Medical Laboratory) and Jerry Katzmann (Mayo Clinic) on testing for monoclonal gammopathies. A meeting of the Specialty Committee of the Royal College for Medical Biochemistry followed this where again the major topic of this meeting was the re-alignment of the training requirements for the specialty.

Day 2 began with the business meeting of the AMBQ. The scientific sessions began that afternoon with a session on "HbA1C and Diabetes Monitoring" chaired by Dr. Julie StCyr (SMH). The first speaker, Dr. Andrew Don-Wauchope (McMaster University), in his talk "HbAlc: Truth or Politics in the published recommendations" reviewed the latest recommendations by the CSCC and CAMB and the rationale behind these recommendations. This was followed by Dr. Sylvie Bertrand (Centre Hospitalier Université Montréal), who reviewed "Insulin Therapy in 2010" for adults. The morning session ended with an entirely different perspective with Dr. Constatin Polychronakos's (MUHC) presentation "HbAlc and the Management of Type 1 Diabetes: The Pediatric Perspective".

The Day 3 morning session, moderated by Dr. Andre Mattman (University British Colombia), focused on the Personalized Genome. The first speaker was Dr. Mark Trifiro
(JGH) who provided a comprehensive review of the androgen receptor and mutations in its gene in relationship to development of cancer. This was followed by a presentation by Dr. Tommy Nilsson (MUHC) who guided the audience through liver function as viewed through the prism of cell biology and proteomics. The morning ended with a talk by Dr. Yann Joly (McGill University) on the ethical aspects of personalized medicine. He reminded us that although this is a new field old, concerns still arise (e.g. genetic overgeneralization, genetic determinism, genetic exceptionalism).

Day 4, the last day, was primarily dedicated to oral presentations by the medical residents. A jury consisting of Drs. Jean Dubé (Centre Hospitalier Université Sherbrooke), Pierre Douville (Centre Hospitalier Université Laval), and Pierre Leclerc (Centre Hospitalier Université Laval) had the "difficult" task of awarding prizes to the best oral presentations. The winners this year were Dr. Ann Gangloff (CHUQ) for the oral presentation entitled "A novel mutation of ApoB in a member of a French Canadian family with hypobetalipoproteinemia " and Dr. Ahlem Chouiali for the oral presentation entitled "Une Néoplasia Tellement Atypique". The scientific portion of the conference ended with a most comprehensive presentation on analytical strategies for detection of "doping" in sports by Dr. Christine Ayotte (INRS-Institute Armand-Frappier). Dr. Ayotte reminded us that there is a continual evolutionary struggle between those developing new doping agents and those trying to detect these agents.

The day and the congress ended with a business meeting of the CAMB chaired by the president, Dr. Elizabeth MacNamara. A new executive was elected: Dr. Dr. Andrew DonWauchope (McMaster U. Health Sciences Centre, vicepresident), Dr. Brian M. Gilfix (MUHC, secretary-treasurer), and Dr. Pierre Douville (CHUS, councilor). Dr. Andre Mattman (BCCWHC), Dr. Yves Guigère (CHUQ, councilor) and Dr. John Heathcote (Vancouver, councilor) continued as councilors.

We all look forward to next year's combined meeting, which is slated to take place in Quebec City in October, 2011. 


\section{Une néoplasie tellement atypique...}

Chouiali, A. et Dubé, J.

Centre Hospitalier Université Sherbrooke. Sherbrooke QC

Introduction: Les atteintes paranéoplasiques hépatiques peuvent occasionner des ictères très importants avec des perturbations du bilan biochimique.

Objectif: Reconnaitre l'impact des atteintes hépatiques cholestatiques sévères sur le bilan biochimique. Reconnaitre une atteinte hépatique d'allure paranéoplasique imputée à une néoplasie d'une extrême rareté.

Observation: Nous rapportons l'observation d'un patient de 60 ans d'origine canadienne-française, ayant une histoire de dyslipidémie non traitée et de dorsalgie chronique modérément soulagée par le celebrex. Ce patient a été transféré en urgence au CHUS pour ictère franc d'installation aigüe. À l'examen physique, il présentait un tableau de cholestase. Les analyses de laboratoire révélaient une atteinte hépatique mixte avec sérologie virale et AAM négatifs. L'échographie abdominale ne démontrait pas de cholestase d'obstruction. L'investigation plus poussée confirme le diagnostic de néoplasie rare. Cette néoplasie explique son atteinte hépatique et la répercussion de celle-ci sur le bilan biochimique en particulier les bilans électrolytique et lipidique.

Conclusion: Les cliniciens et le laboratoire devraient demeurer vigilants devant l'influence des pathologies hépatiques sur le bilan biochimique en particulier les bilans électrolytique et lipidique.

\section{A novel mutation of ApoB in a member of a french canadian family with hypobetalipoproteinemia}

Gangloff, A. ${ }^{1}$, Gagné, C. ${ }^{1}$, Martins, R. ${ }^{2}$, Couture, P. ${ }^{1}$, Hegele, R.A. ${ }^{2}$, et Bergeron, J1 .

${ }^{1}$ Lipid Research Centre, CHUQ research centre, Quebec City, QC

${ }^{2}$ Robarts Research Institute, University of Western Ontario, London, Ontario

Introduction: We report the case of a 27 year-old woman diagnosed with hypobetalipoproteinemia during her first year of life. Her parents are distant cousins and have 12 children, of whom 3 (the proband and 2 younger brothers) have confirmed hypobetalipoproteinemia.

Observations: Clinical data - Signs and symptoms at diagnosis included diarrhea and acanthocytosis on the blood smear. Vitamins A, D and E were started in childhood, but compliance has been uncertain. Supplements and medical follow-up were stopped between ages 18 and 25 years. The patient denies any neurological symptoms other than diminished visual acuity in the left eye. Physical examination - weight $=58 \mathrm{~kg}$, height $=151,5 \mathrm{~cm}$, waist $=79 \mathrm{~cm}, \mathrm{BMI}=25 \mathrm{~kg} / \mathrm{m}^{2}, \mathrm{BP}=95 / 69 \mathrm{~mm} \mathrm{Hg}$. The remainder of the physical exam and an abdominal ultrasound were normal. Laboratory results - lipid profile: $\mathrm{TC}=0,31 \mathrm{mmol} / \mathrm{L}$, triglycerides= $0,15 \mathrm{mmol} / \mathrm{L}, \mathrm{HDL}=0,29 \mathrm{mmol} / \mathrm{L}, \mathrm{LDL}<0,50 \mathrm{mmol} / \mathrm{L}$, ApoB- $100<0,25 \mathrm{~g} / \mathrm{L}$. Normal ALT with slightly increased AST. Lipophilic vitamins: $B$-carotene $<0,01 \mu \mathrm{mol} / \mathrm{L}(0,12-2,05 \mu \mathrm{mol} / \mathrm{L})$, vitamin $A=0,22 \mu \mathrm{mol} / \mathrm{L}(1,33-3,42 \mu \mathrm{mol} / \mathrm{L})$, alpha-tocopherol $($ Vitamin $\mathrm{E})=1 \mu \mathrm{mol} / \mathrm{L}(13-42 \mu \mathrm{mol} / \mathrm{L})$. Vitamin D was normal. Marked acanthocytosis was present on the blood smear with slightly low hemoglobin levels $(111 \mathrm{~g} / \mathrm{L}$ to $129 \mathrm{~g} / \mathrm{L})$. The following were normal: serum iron, B12 and folate. An indirect hyperbilirubinemia was documented.

Genetic - A novel homozygous coding mutation in APOB (G275, T276V>300X) was identified. The DNA sequence encodes a severely truncated ApoB protein (300 aa instead of 4536 aa, $7 \%$ of the normal length).

Conclusion: We report a French Canadian patient with familial hypobetalipoproteinemia characterized by undetectable levels of apoB secondary to a homozygous early stop codon. 


\section{Métabolisme du manganèse au cours de la nutrition parentérale à long terme}

Boumati, B.M., Radwan, R.F., et Kadri, K.N.

Hôpital Notre Dame du CHUM, Montréal, QC

Introduction: Le manganèse est un élément trace essentiel, ajouté à des concentrations fixes aux solutions de nutrition parentérale, (la littérature récente a identifié des problèmes en lien avec cette approche)

Méthodes: Revue de littérature : 11 articles de 1999-2009 et revue du dossier de la patiente.

Nous rapportons un cas d'hypermanganésemie chez une patiente ayant reçu la nutrition parentérale pendant environ 16 mois.

Le principal mécanisme de régulation de l'homéostasie du manganèse est la diminution de l'absorption intestinale, l'administration parentérale contourne ce mécanisme. De plus l'élimination se fait essentiellement par le système hépatobiliaire, qui est souvent détérioré chez les patients sous nutrition parentérale. L'ensemble de ces facteurs entrainerait une élévation des concentrations du manganèse dans le sang avec accumulation au niveau du cerveau et neurotoxicité.

Résultats: Une surveillance régulière est recommandée. Les concentrations dans le sang total sont plus précises et corrèlent avec les changements de l'intensité du signal en imagerie par résonnance magnétique du cerveau, cependant l'association entre ces mesures et les symptômes cliniques n'est pas établie.

Les recommandations pour la suplémentation des éléments traces requiert une révision afin d'individualiser les formules de dosages en nutrition parentérale à long terme.

Une surveillance fréquente pour détecter une accumulation du manganèse dans le cerveau est recommandée.

Conclusion: Avec l'évidence de la croissance de toxicité au manganèse associé à la nutrition parentérale et la présence de cas très rares de déficit, la suplémentation systématique en manganèse chez les patients en nutrition parentérale à long terme ne serait pas nécessaire.

\section{Effects of blood and blood product transfusion on newborn metabolic screening for biotinidase deficiency}

Huston, A. and Bamforth, F.

Department of Laboratory Medicine and Pathology, University of Alberta, Edmonton, AB

Background: Biotinidase deficiency screening is included in many newborn screening programs. Blood or blood products transfused prior to sample collection potentially may cause a false negative newborn screen in a newborn with biotinidase deficiency.

Objectives: To evaluate biotinidase activity in blood products typically transfused in a neonate and to assess likelihood of a false negative newborn screen.

Materials and methods: Biotinidase activity was measured semi-quantitatively by incubating dried blood spots overnight with $\mathrm{N}$ biotinyl-PABA, and measuring the released PABA colorimetrically. Biotinidase activity was measured in the following products: packed red cells, platelets (pooled and apheresis), human albumin 5\% and 20\% USP (Plasbumin ${ }^{\circ}$ ) and frozen plasma. If biotinidase activity was present, the product was mixed with biotinidase deficient blood (prepared by heat inactivation of enzyme in serum and reconstituting with washed red blood cells) to simulate typical transfusion volumes (Canadian Blood Services guidelines) for a $2.72 \mathrm{Kg}$ neonate.

Results: Prepared biotinidase deficient blood showed no biotinidase activity. Biotinidase activity was absent in packed red cells and albumin (5\% and 20\%) but present in platelets and frozen plasma. The interpretation of the biotinidase screen after simulated transfusion of platelets and frozen plasma to biotinidase deficient blood was as follows: platelets $\leq 10 \mathrm{~mL} / \mathrm{Kg}$ body weight: Profound deficiency; platelets $\geq 15 \mathrm{~mL} / \mathrm{Kg}$ : Partial deficiency; frozen plasma $\leq 5 \mathrm{~mL} / \mathrm{Kg}$ : Partial deficiency; frozen plasma $\geq 10 \mathrm{~mL} /$ $\mathrm{Kg}$ : Normal biotinidase activity. 
Conclusion: Newborns with biotinidase deficiency receiving high dose platelet transfusion or standard dose plasma transfusion may have a false negative newborn biotinidase screen.

\section{Determination of trimester-specific refrefnce ranges for thyroid function in pregnant women: are they necessary?}

Amari, M.A. , Giguère, Y., et Girouard, J.

Centre Hospitalier Université Laval, Québec, QC

Background: Thyroid disease can affect pregnancy and adequate thyroid function is important for fetal development as well. To ensure that thyroid status is correctly evaluated in pregnant woman, the reference range against which tests results are compared must be optimally defined for the stage of pregnancy.

Study design: The project aimed to define reference ranges for the pregnant women population followed at the CHUQ. Three subgroups of pregnant women based on gestational age in weeks were tested: [14-16] [24-28] and [28-36]. A $4^{\text {th }}$ group that will include only first trimester [9-13] is currently being set up. Women in each group were tested anonymously for TSH, Free T4 and Total T3, and Anti-TPO on Roche Modular system.

Results: $13 \%$ of women were excluded for the presence of elevated anti-TPO antibodies. Using percentiles 2.5 and 97.5 we determined reference range for TSH. For the FT4 and TT3, two sets of reference ranges were calculated: one based on 2.5th and 97.5th and the other based on entire range of those having TSH within determined reference range. The results are shown below.

\begin{tabular}{|c|c|c|c|c|c|c|c|c|c|}
\hline Group & [9-13] & \multicolumn{2}{|c|}{$[14,18]$} & \multicolumn{2}{|c|}{$[24,28]$} & \multicolumn{2}{|c|}{$[28,36]$} & \multicolumn{2}{|c|}{ Non pregnant adults } \\
\hline \multirow[t]{2}{*}{$\mathbf{n}$} & target $=100$ & \multicolumn{2}{|c|}{88} & \multicolumn{2}{|c|}{72} & \multicolumn{2}{|c|}{100} & \multicolumn{2}{|c|}{ Range currently in use } \\
\hline & Lower RL* Upper RL & Lower RL & Upper RL & Lower RL & Upper RL & Lower RL & Uррет RL & Lower RL & Upper RL \\
\hline TSH & In progress & 0,6 & 3,8 & 0,35 & 4,7 & 0,65 & 5,2 & 0,25 & 5 \\
\hline Free T4 & In progress & 10,5 & 16,4 & 8,4 & 15,5 & 7,9 & 16,2 & 12 & 22 \\
\hline Total T3 & In progress & 1,75 & 3,75 & 1,7 & 3,8 & 1,5 & 4,05 & 1,2 & 3 \\
\hline
\end{tabular}

${ }^{*}$ RL means reference limit.

The upper reference limit for TSH is lower earlier in pregnancy. FT4 reference limits drift towards lower values as pregnancy progresses.

Conclusion: This suggests the need of trimester-specific reference ranges for thyroid function tests in pregnancy to optimize pregnancy outcome and healthcare service use.

\section{Impact du test statistique dans la comparaison d'échantillons indépendants}

Zenagui, $\mathrm{S}^{1}$. et Larivière, $\mathrm{F}^{2}$.

${ }^{1}$ Université de Montréal. ${ }^{2}$ Centre Hospitalier de l'Université de Montréal, Montréal, QC

Objectifs : La comparaison de deux échantillons indépendants soulève souvent le problème du choix du test statistique optimal. Les recommandations usuelles discutent rarement l'impact que peut avoir le choix du test sur sa performance. Nous avons donc voulu explorer les conséquences du choix du test statistique sur la valeur réelle du niveau de signification par rapport à sa valeur nominale.

Méthodes : Le logiciel $\mathrm{R}$ a été utilisé pour effectuer de l'échantillonnage multiple sur des populations de distribution symétrique et asymétrique. Les valeurs réelles du niveau de signification des 3 tests statistiques suivants, t de Student, Welch et Wilcoxon-Mann- 
Whitney ont été comparées à la valeur nominale de 0.05.L'impact de l'inégalité des variances des populations sous-jacentes a été étudié.

Résultats : Dans le cas d'échantillons de taille égale provenant d'une distribution normale, le niveau de signification oscille entre 0.041 et 0.061 et cela pour des ratios de variance allant de 0.25 à 9 . Pour une distribution gamma, à variance égale les trois tests ont des résultats similaires (0.045-0.047). Par contre, lorsque les échantillons sont de variance inégale, le test de Welch est celui qui respecte le plus le niveau de signification (0.052-0.072), alors que le test de Wilcoxon-Mann-Whitney est celui qui respecte le moins la valeur nominale (0.076-0.172).

Conclusions: Le choix d'un test statistique peut influencer de façon importante le niveau de signification d'un test.

\section{Can myoglobin be used as a marker of skeletal muscle mass in cancer patients?}

Grunbaum, A. ${ }^{1}$, Van Der Borch, C. ${ }^{1}$, Murphy, R. ${ }^{2}$, Eintracht, S. ${ }^{1}$, Atherton, J. ${ }^{1}$, Baracos, V. ${ }^{2}$, Mazurak, V. ${ }^{2}$, MacNamara, E. ${ }^{1}$, and Jagoe, R.T. ${ }^{1}$

1Jewish General Hospital and McGill University, Montreal, QC; ${ }^{2}$ University of Alberta, Edmonton, AB

Objectives: In cancer and chronic disease, muscle wasting is found in all categories of body mass index and is a strong negative prognostic factor (Lancet Oncol, 2008;9(7):629-635) (Am J Respir Crit Care Med, 2002;166(6):809-813). A simple method of quantifying total skeletal muscle mass (SMM) would be very useful for early identification of muscle wasting in cancer, and in monitoring impact of rehabilitation interventions aimed at increasing muscle mass. One prior study suggested that plasma myoglobin (Mb) correlates well with SMM in cancer patients ( $\mathrm{J} \mathrm{Mol} \mathrm{Med,2007;85(8):887-896),} \mathrm{thus} \mathrm{Mb} \mathrm{may} \mathrm{be} \mathrm{a} \mathrm{biochemical} \mathrm{marker}$ of muscle mass. Our study aimed to confirm whether Mb correlated with SMM, and to test whether changes in Mb were sufficiently sensitive to detect meaningful changes in SMM over time.

Methods: Data was obtained from 22 patients with non-small cell lung or colorectal cancer, undergoing chemotherapy. Two blood draws, taken at least 4 weeks apart, were selected for each patient. Mb was correlated with a precise and specific estimate of SMM determined by analysis of CT images (Lancet Oncol, 2008;9(7):629-635) from scans performed within 25 days of each blood draw.

Results: No consistent correlation between $\mathrm{Mb}$ and $\mathrm{SMM}$ was found. However change in $\mathrm{Mb}$ was negatively correlated with change in $\operatorname{SMM}(\mathrm{p}=0.02, \mathrm{R}=-0.56)$.

Conclusions: Change in $\mathrm{Mb}$ shows promise as a simple biochemical method to detect changes in SMM. In contrast to prior studies these results suggest that change in $\mathrm{Mb}$ is inversely related to change in $\mathrm{SMM}$, and $\mathrm{Mb}$ is not a direct marker of muscle mass.

\section{Thyrotoxic hypokalemic periodic paralysis}

Fung, V., and Mattman, A.

Department of Medical Biochemistry, University of British Columbia, Vancouver, B.C.

Introduction: A 31 year old Asian male was brought to the emergency department (ER) with a history of complete paralysis of his lower limbs.

Observations: His past medical history was significant for hyperthyroidism but he was lost to follow-up for 2 years after immigrating from Taiwan. He was given a large supply of Tapazole prior to leaving his home country. He continued to take it at a dose of 5 mg once daily without seeking medical advice and without any laboratory monitoring in Canada. On presentation, he was alert and oriented but physical findings were significant for weakness in his lower extremities (grade $2 / 5$ in motor strength) and absent deep tendon reflex at the knees in addition to signs of hyperthyroidism. Serum potassium of $1.9 \mathrm{mmol} / \mathrm{L}$ (normal range 3.5-5.0) $\mathrm{mmol} / \mathrm{L}$. His CK level was 587 (normal range 52-175) U/L. Other initial laboratory investigations were normal: complete blood count, electrolytes, random glucose and renal function test. He was immediately placed on cardiac monitoring and given potas- 
sium IV and oral propanolol. His ECG showed normal sinus rhythm with no evidence of QT prolongation or ST-segment changes. His lower limb weakness gradually improved over next 2 to 4 hours. The results of thyroid function testing revealed complete suppression of TSH $<0.01 \mathrm{mU} / \mathrm{L}$, an elevated fT 4 of 34.5 (normal range 11-22) pmol/L, and a fT3 of 12.5 (normal range 3.5-6.5) pmol/L. He was medically stabilized and prior to discharge, his dose of Tapazole was increased to $10 \mathrm{mg}$ once daily and was given a prescription for propanolol $20 \mathrm{mg}$ p.o. bid.

Conclusion: The patient was confirmed to demonstrate classic diagnosis of thyrotoxic hypokalemic periodic paralysis. Follow-up was to be at the Endocrinology service in 3-4 weeks time and to find a family physician in the community for continuity of care. 